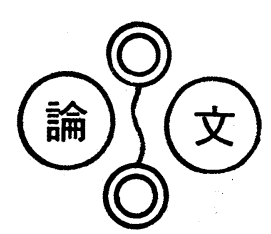

石炭の接触ガス化における触媒活性序列

一岸種，ガス化㓮の影響一

-1983. 2. 7 受理一

東北大学 宝田 恭之, 大塚 康夫

富田彰, 玉井康勝

\section{1. 緒言}

石炭，黒鉛などの炭素質のガス化において，アルカ り金属, 遷移金属などは触媒作用を示し, それらの活性 序列に関しての報告がある1) 4)。たと告鉛の $\mathrm{H}_{2} \mathrm{O}$ ガス化では，McKee らは $\mathrm{Li}>\mathrm{K}>\mathrm{Na}^{5}$ および $\mathrm{Ba}>$ $\mathrm{Sr}>\mathrm{Ca} \approx \mathrm{Mg}^{6)}$ という序列を報告して扣り，アルカリ

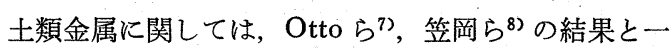
致している。また, 石炭の $\mathrm{H}_{2} \mathrm{O}$ ガス化では, Hippo ら92は褐炭を用いて $\mathrm{K}>\mathrm{Na} \approx \mathrm{Ca}>\mathrm{Fe}>\mathrm{Mg}$ といった 序列を報告している。

われわれは，前報10)で歴青炭である新夕張炭を用い $\tau, \mathrm{K}, \mathrm{Ba}, \mathrm{Fe}, \mathrm{Ni}$ の活性序列和よび各触媒担持炭の 反応のプロプァイル（反応に伴ら反応速度の変化）に 和よぼす触媒担持量, 反応温度, ガス化剂の影響につ いて検討した。その結果, $\mathrm{H}_{2} \mathrm{O}$ ガス化では, $\mathrm{K}>\mathrm{Ba}>$ $\mathrm{Ni}>\mathrm{Fe}, \mathrm{CO}_{2}$ ガス化では $\mathrm{K}>\mathrm{Ba}>\mathrm{Fe}>\mathrm{Ni}, \mathrm{H}_{2}$ ガス 化では $\mathrm{Ni}>\mathrm{Fe}>\mathrm{K}>\mathrm{Ba}$ という序列を得ている。

しかしながら, 石炭は無煙炭から歴青炭, 褐炭に至
るまで非常に種類が多く, それぞれ化学的, 物理的性 状が異なる。ガス化特性と炭化度との関係については 㞸化度が高くなると反応性が低くなることが知られて いる11ー13)。また，現在に拈ける石炭のキャラクタリ ゼーションは十分とはいえず，ある石炭に関する結果 から他の石炭に関する結果を予想することは困難であ る。そこで, 石炭全体としてのより一般的な結果を得 るためには多数の石炭について実験を行う必要があ る。しかし，今までに報告された石炭ガス化に和ける 触媒活性序列は，1〜2種の石炭についての結果であ り，炭種の影響についての知見は得られていない。そ こで本研究では，無煙炭から褐炭まで炭化度の異なる 10 種類の石炭を用いて, $\mathrm{K}, \mathrm{Ba}, \mathrm{Fe}, \mathrm{Ni}$ 各触媒担持炭 の反応のプロファイルおよび活性序列に対する炭種依 存性について検討を行った。また， 3 種類のガス化剤 を用いて，ガス化剤の影響についても検討した。

\section{2. 実 験}

Table 1 Analysis of coals

\begin{tabular}{|c|c|c|c|c|c|c|c|c|c|c|c|}
\hline \multirow{2}{*}{ No. } & \multirow{2}{*}{ Coal } & \multicolumn{5}{|c|}{ Ultimate analysis (wt $\%$, daf) } & \multicolumn{4}{|c|}{ Proximate analysis $(w t \%)$} & \multirow{2}{*}{$\mathrm{CSN}^{11}$} \\
\hline & & $\mathrm{C}$ & $\mathrm{H}$ & $\mathrm{N}$ & $\mathrm{S}$ & $\mathrm{O}$ & M. & V.M. & $\mathrm{F}: \mathrm{C}$ & Ash & \\
\hline 1 & Hongay (Vietnam) & 93.7 & 3.3 & 1.3 & 0.4 & 1.3 & 1.6 & 7.2 & 86.8 & 4.4 & 0 \\
\hline 2 & Shin-Yubari (Japan) & 86.9 & 5.6 & 1.9 & 0.3 & 5.3 & 1.1 & 38.0 & 55.8 & 5.1 & $71 / 2$ \\
\hline 3 & Tatung-Yunkang (China) & 82.7 & 5.0 & 0.9 & 0.7 & 10.7 & 5.5 & 29.5 & 62.8 & 2.2 & $11 / 2$ \\
\hline 4 & Grose Valley (Aust.) & 81.7 & 5.1 & 1.4 & 0.4 & 11.4 & 3.4 & 29.7 & 50.3 & 16. 6 & 1 \\
\hline 5 & Akabira (Japan) & 80.8 & 6.2 & 1.9 & 0.7 & 10.4 & 2.8 & 41.8 & 49.2 & 6.2 & $31 / 2$ \\
\hline 6 & Leopold (FRG) & 79.9 & 5.8 & 1.4 & 1.2 & 11.7 & 3.3 & 38.7 & 54.7 & 3.3 & 3 \\
\hline 7 & Taiheiyo (Japan) & 76.8 & 6.4 & 1.5 & 0.3 & 15.0 & 5.8 & 46.5 & 36.9 & 10.8 & 0 \\
\hline 8 & Wandoan (Aust.) & 75.8 & 6.8 & 1.0 & 0.3 & 16.1 & 9.1 & 49.0 & 25.0 & 16.9 & 0 \\
\hline 9 & South Beulah (USA) & 71.6 & 4.8 & 1.5 & 2.9 & 19.2 & 18.1 & 31.6 & 39.1 & 11.2 & 0 \\
\hline 10 & Yallourn (Aust.) & 66.1 & 5.3 & 0.6 & 0.3 & 27.7 & 14.3 & 47.3 & 37.6 & 0.8 & 0 \\
\hline
\end{tabular}

1) CSN : Crucible Swelling Number 
実験に使用した石炭は10種類で，それらの工業分析 值，元素分析值执よびボタン指数を Table 1 に示す。 石炭の選択に際して着目した因子は石炭中の炭素含有 量であり, 無煙炭の Hongay 炭から褐炭の Yallourn 炭まで広い範囲の石炭を選択した。

触媒には，アルカリ金属としてK, アルカリ土類金 属として Ba，第收族遷移金属として Fe, $\mathrm{Ni}$ 選び, 触 媒担持の出発物質としては, $\mathrm{K}_{2} \mathrm{CO}_{3}, \mathrm{Ba}\left(\mathrm{CH}_{3} \mathrm{COO}\right) 2$, $\mathrm{Fe}\left(\mathrm{NO}_{3}\right)_{3}, \mathrm{Ni}\left(\mathrm{NH}_{3}\right)_{6} \mathrm{CO}_{3}$ の各塩を用いた。各塩の 溶液の濃度は, 約 $90 \mathrm{mg}-\mathrm{Metal} / \mathrm{cc}$ である。以下, 本 論文では上記の各触媒を $\mathrm{K}, \mathrm{Ba}, \mathrm{Fe}, \mathrm{Ni}$ ま, 各触媒 担持炭を $\mathrm{K}$ 担持炭, $\mathrm{Ba}$ 担持炭, $\mathrm{Fe}$ 担持炭, $\mathrm{Ni}$ 担持 炭と表わす。

触媒担持は, 前報 ${ }^{10)}$ と同様，モルター・グラインダ 一を用いて触媒溶液中で石炭を粉砕, 混練することに より行った。触媒担持量は, 各恒湿石炭に対して金属 として $10 \mathrm{wt} \%$ である。10炭種と 4 触媒のすべての組み 合わせについて担持を行い，無触媒の試料を含め， 50 種類の試料を調整した。

新夕張炭と同様 ${ }^{10)}$, 本実験において使用した粘結炭 に拈いても，触媒担持によって粘結性の低下が認めら れた。新夕張炭を含めた 5 種の粘結炭の各担持炭のボ タン指数を Table 2 に示す。全体的に判断すると, 粘 結性低下の効果は $\mathrm{Fe}$ を担持した場合が最も大きく, 以下, $\mathrm{K}>\mathrm{Ni}>\mathrm{Ba}$ の順である。担持炭の粘結性低下 の原因のひとつとして, 担持に用いた触媒塩のアニオ ンによる酸化が考光られる。とくに, Fe 触媒 (Fe (NO3)3）を担持した場合の粘結性低下は, アニオンに よる酸化の影響が大きいと思われる。

\section{2 ガス化}

ガス化の方法も前報 ${ }^{10)}$ と同様で, 真空理工製の熱天 科を用いて行い, 重量減少より転化率を求めた。ガス 化剤としては, $\mathrm{H}_{2} \mathrm{O}, \mathrm{CO}_{2}, \mathrm{H}_{2}$ を用い, $\mathrm{H}_{2} \mathrm{O}$ ガス化 は 873 1023K, $\mathrm{CO}_{2}$ ガス化は 923〜1123K, H2 ガス 化は $1273 \mathrm{~K} て ゙$ 行った。反応温度は, あらかじめ温度を

Table 2 Crucible swelling number

\begin{tabular}{lllllll}
\hline & \multicolumn{4}{c}{ Crucible swelling number } \\
\cline { 2 - 6 } \multicolumn{1}{c}{ Coal } & $\begin{array}{c}\text { Original } \\
\text { coal }\end{array}$ & $\mathrm{K}$ & $\mathrm{Ba}$ & $\mathrm{Fe}$ & $\mathrm{Ni}$ \\
\hline Shin-Yubari & $71 / 2$ & $11 / 2$ & $21 / 2$ & 0 & 3 \\
Tatung-Yunkang & $11 / 2$ & 0 & 0 & 0 & 0 \\
Grose Valley & 1 & 0 & 0 & 0 & 0 \\
Akabira & $31 / 2$ & 0 & $11 / 2$ & 0 & 0 \\
Leopold & 3 & 0 & 1 & 0 & 0 \\
\hline
\end{tabular}

変えた実験を行い, 各無触媒炭の反応性がほぼ等しく なるように設定した。反応時間は 2 時間であり，反応 終了後の残渣を空気で然焼し; 触媒を含めた灰分量を 実験ごとに確認した。また，同一条件での実験を少な くとも2 回以上くり返して行ったが, 再現性は良好で あった。ただし， $\mathrm{H}_{2}$ ガス化において，Baを担持した 赤平炭と Tatung-Yunkang 炭のデータのバラッキは 大きかった。燃焼後 (空気, 973K) の残椬を観察した ところ，黒い部分があり，完全に燃え切っていない場 合もあることがわかったので, 燃焼後の残渣が白い場 合のデータのみを採用した。

\section{3. 結果と考察}

$3.1 \mathrm{H}_{2} \mathrm{O}$ ガス化における反応のプロファイル

触媒の活性序列を決める前に, 各触媒担持炭の反応 のプロファイルを把握する必要がある。前報(10)で, 反応 のプロファイルは, 扣もに触媒の種類, 触媒担持量, ガ ス化剂に影響されることがわかった。新夕張炭に各触 媒を担持したものは，それぞれ固有のプロファイルを 持ら,たとえば $\mathrm{H}_{2} \mathrm{O}$ ガス化に拈ける残存チャーあたり の反応速度は, 反応の進行に伴い, $\mathrm{Fe}$ 担持炭, $\mathrm{Ba}$ 担 持炭では減少, $\mathrm{Ni}$ 担持炭では一定, K担持炭では増加 する傾向にあることが認められた。そこで，新夕張炭 で認められた各触媒担持炭の反応のプロファイルが石 炭全体として一般的であるかどうか，つまりプロファ イルに対する炭種依存性について検討を加える。

以下，本論文で用いる反応速度は，残存チャ一重量 (w) あたりの Specific rate $(r=-1 / \mathrm{w} \cdot \mathrm{dw} / \mathrm{dt})$

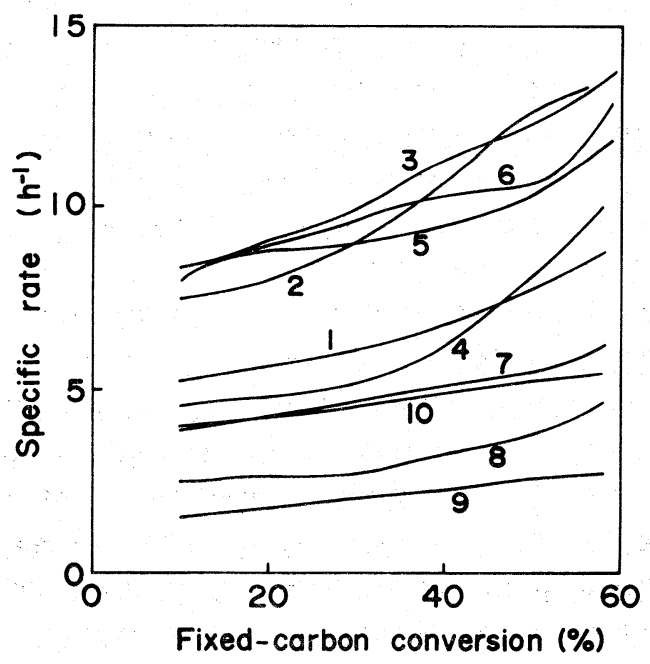

Fig. 1 Variation of specific rate for the potassium-catalyzed steam gasification of ten coals 
Table 3 Parameter $\left(\mathbf{r}_{30} / \mathbf{r}_{10}\right)$ for the steam gasification profile

\begin{tabular}{|c|c|c|c|c|c|c|c|c|c|c|c|}
\hline \multirow{2}{*}{ Coal } & \multirow{2}{*}{$\underset{(\mathrm{K})}{\text { Temp. }}$} & \multicolumn{2}{|c|}{ None } & \multicolumn{2}{|c|}{$\mathrm{K}$} & \multicolumn{2}{|c|}{$\mathrm{Ba}$} & \multicolumn{2}{|c|}{$\mathrm{Fe}$} & \multicolumn{2}{|c|}{$\mathrm{Ni}$} \\
\hline & & $\mathrm{r}_{10}\left(\mathrm{~h}^{-1}\right)$ & $\mathrm{r}_{20} / \mathrm{r}_{10}$ & $\mathrm{r}_{10}\left(\mathrm{~h}^{-1}\right)$ & $\mathrm{r}_{30} / \mathrm{r}_{10}$ & $r_{10}\left(h^{-1}\right)$ & $r_{30} / r_{10}$ & $r_{10}\left(h^{-1}\right)$ & $\mathrm{r}_{30} / \mathrm{r}_{10}$ & $\mathrm{r}_{10}\left(\mathrm{~h}^{-1}\right)$ & $\mathrm{r}_{30} / \mathrm{r}_{10}$ \\
\hline Hongay & 1023 & 0.15 & 0.9 & 5.3 & 1.2 & 1.1 & 0.4 & 0.24 & 0.8 & 0.3 & 0.8 \\
\hline Shin-Yubari & 1023 & 0.18 & 0.8 & 7.5 & 1.2 & 2.8 & 0.9 & 1.1 & 0.3 & 1.0 & 1.0 \\
\hline Tatung-Yunkang & 1023 & 0.20 & 0.7 & 8.0 & 1.3 & 5.1 & 0.9 & 0.87 & 0.5 & 1.1 & 0.8 \\
\hline Grose Valley & 1023 & 0.20 & 0.8 & 4.6 & 1.1 & 4.4 & 0.5 & 0.28 & 0.7 & 1.0 & 0.4 \\
\hline Akabira & 1023 & 0.24 & 0.7 & 8.4 & 1.2 & 3.8 & 0.9 & 0.57 & 0.5 & 1.6 & 0.7 \\
\hline Leopold & 1023 & 0.15 & 0.9 & 8.3 & 1.3 & 2.5 & 0.7 & 0.36 & 0.5 & 1.3 & 1.0 \\
\hline Taiheiyo & 923 & 0.23 & 1.0 & 4.0 & 1.2 & 1.0 & 0.6 & 0.36 & 0.5 & 0.3 & 0.9 \\
\hline Wandoan & 923 & 0.27 & 0.8 & 2.5 & 1.1 & 1.1 & 0.6 & 0.48 & 0.4 & 7.6 & - \\
\hline South Beulah & 873 & 0.24 & 0.6 & 1.6 & 1.3 & 0.84 & 0.7 & 0.59 & 1.0 & 0.3 & 1.1 \\
\hline Yallourn & 923 & 0.16 & 0.4 & 4.0 & 1.1 & 2.0 & 0.4 & 0.66 & 0.9 & 14 & - \\
\hline
\end{tabular}

$\mathrm{r}_{10}$ : Specific rate at $10 \%$ conversion

$\mathrm{r}_{20}$ : Specific rate at $20 \%$ conversion

$r_{30}$ : Specific rate at $30 \%$ conversion

である。この速度が一定ならば，その反応は一次反応 である。また，転化率は，すべて，揮発分を除いた固 定炭素転化率 (Fixed-carbon conversion) である。

K担持炭の反応のプロファイルを Fig.1 に示す。困 中の番号は Table 1 の石炭番号である。反応温度は, South Beulah 炭は 873K, Yallourn 炭, Wandoan

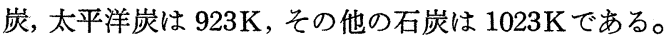
転化率10\%未満の反応速度は，乾留との区別が難しい ので求めず, 図には示していない。使用した10炭種すべ てにおいて，K担持炭の反応速度は反応の進行に伴い 增加する。初期重量あたりの速度にすると，ほぼ一定と なる。この傾向は，すでに見出されていたものである が，本実験によって無煙炭から褐炭までの広い範囲の 石炭に执いて一般的な傾向であることが確認された。

次に，穴の他の触媒については，転化率10\%と $30 \%$ における速度(それぞれ $\mathrm{r}_{10}, \mathrm{r}_{30}$ とする)の比を用いて プロファイルの傾向をとらえる。ここでは，プロファ イルの詳細を検討するのではなく，反応速度が反応の 進行伴い，増加するか，減少するか，一定であるか といったきわめて概略的な傾向をとらえることを目的 とする。Table 3 亿 $\mathrm{H}_{2} \mathrm{O}$ ガス化に拈ける $\mathrm{r}_{10}$ と $\mathrm{r}_{30} / \mathrm{r}_{10}$ を示す。ただし，無触媒炭は 2 時間の反応では $30 \%$ に 達しないものもあったので， $\mathrm{r}_{20} / \mathrm{r}_{10}$ を示す。 $\mathrm{Ba}$ 担持 炭の $\mathrm{r}_{30} / \mathrm{r}_{10}$ は0.4 0.9の間にあり, 速度は減少の傾向 にある。このような反応中の活性の低下の原因として 石炭中の硫黄分中鉱物質との反応 ${ }^{814}$ 亿上る活性低下 が考兄られる。灰分の多い石炭 (Grose Valley 炭, 太平洋炭, Wandoan 炭, South Beulah 炭) の速度
低下の原因のひとつは，少なくともこのような理由に よるものであろう。Fe 担持炭は，汪とんどが急激な 速度の減少を示す。 $\mathrm{Fe}$ 触媒は酸化物になると活性が 低下することが知られて和り ${ }^{715)}, \mathrm{Fe}$ 担持炭の反応の プロファイルに反映されているものと思われる。しか し, 原因は不明であるが, South Beulah炭, Yallourn 炭に执いては，ほぼ一定で初期の速度を持続してい る。 $\mathrm{Ni}$ 担持炭は, Grose Valley 炭の速度低下が急激 な汪かは，やや減少あるいは一定である。すなわち， $\mathrm{Ni}$ 触媒は初期速度をある程度持続することができ, 同じ遷移金属の $\mathrm{Fe}$ と比べると，その差は歴然として いる。な技, Yallourn 炭一Ni, Wandoan 炭一Ni の

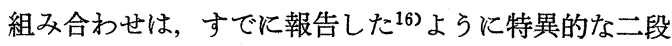
反応を示し，他の石炭とそのプロファイルが著しく異 なるので，表には示していない。

以上, $\mathrm{H}_{2} \mathrm{O}$ ガス化に执いて, 反応のプロファイル は多少の例外はあるものの，㴗ぼ触媒ごとに決まり， 新夕張炭でみられた傾向が，注とんどの石炭で認めら れた。すなわち，反応の進行に伴って，K担持炭の速 度は増加, $\mathrm{Ba}, \mathrm{Fe}, \mathrm{Ni}$ 各担持炭の速度は減少であり, 減少の程度は $\mathrm{Ni}<\mathrm{Ba}<\mathrm{Fe}$ の順である。

\section{2 反応のプロファイルに対するガス化剤の影響}

$\mathrm{CO}_{2}$ ガス化拉よび $\mathrm{H}_{2}$ ガス化に括いて, 全炭種に対 して反応のプロファイルを検討したところ, $\mathrm{H}_{2} \mathrm{O}$ ガス 化と同様，炭種によってその程度は異なるが，全体的 な傾向は触媒によって決まることが認められた。ここ では，すべてのデータを示す代りに，10炭種の $\mathrm{r}_{30} / \mathrm{r}_{10}$ の平均值を用いてガス化剂の影響を検討する。Table 
Table 4 Average $\mathbf{r}_{30} / \mathbf{r}_{10}$ values

\begin{tabular}{lllll}
\hline \multirow{2}{*}{ Gas } & \multicolumn{4}{c}{$\mathrm{r}_{30} / \mathrm{r}_{10}$} \\
\cline { 2 - 5 } & $\mathrm{K}$ & $\mathrm{Ba}$ & $\mathrm{Fe}$ & $\mathrm{Ni}$ \\
\hline $\mathrm{H}_{2} \mathrm{O}$ & 1.2 & 0.7 & 0.6 & 0.8 \\
$\mathrm{CO}_{2}$ & 1.3 & 0.9 & 0.7 & 1.1 \\
$\mathrm{H}_{2}$ & 0.6 & 0.7 & 1.1 & 1.0 \\
\hline
\end{tabular}

4 に $\mathrm{r}_{30} / \mathrm{r}_{10}$ の平均値を示す。 $\mathrm{CO}_{2}$ ガス化において, $\mathrm{K}$ 担持炭の速度は増加, $\mathrm{Ba}$ 担持炭はやや減少, $\mathrm{Fe}$ 担持 炭は減少, $\mathrm{Ni}$ 担持炭はやや増加の傾向を示す。 $\mathrm{H}_{2} \mathrm{O}$ ガス化と比べると, $\mathrm{Ni}$ 担持炭のプロファイルが若干 異なるほかは, ほとんど同様のプロファイルを示すこ とがわかる。 $\mathrm{H}_{2}$ ガス化では, $\mathrm{H}_{2} \mathrm{O}, \mathrm{CO}_{2}$ ガス化に比 べて各担持炭のプロファイルは著しく異なる。すなわ ち, $\mathrm{Fe}$ 担持炭, $\mathrm{Ni}$ 担持炭の $\mathrm{r}_{30} / \mathrm{r}_{10}$ はそれぞれ 1.1 , 1.0 であり, 微増または一定の傾向にある。とくに, $\mathrm{H}_{2} \mathrm{O}, \mathrm{CO}_{2}$ ガス化で急激な速度の減少が認められたFe 担持炭の速度が, $\mathrm{H}_{2}$ ガス化では反応の進行とともに 増加した。Fe 触媒は, 還元状態で活性であり, 還元 状態を保つことによってその活性を持続させることが できると考えられている。 $\mathrm{H}_{2}$ ガス化で, 反応ととも に速度が増加するのはこのためであろう。また, K担 持炭は $\mathrm{H}_{2} \mathrm{O}$ ガス化, $\mathrm{CO}_{2}$ ガス化では特のおの $1.2,1.3$ と増加していたが, $\mathrm{H}_{2}$ ガス化では0.6と急激な減少を 示した。この減少の原因のひとつとして $\mathrm{H}_{2}$ ガス化で は, 反応温度が $1273 \mathrm{~K}$ と高いことから，Kの蒸発が考 えられる。実験に使用した石英セルが不透明になるこ とからもKが反応中に蒸発していることは確かであ
り，また，反応残沮から計算すると，炭種によってる 異なるが，担持したKの約半分が蒸発したと思われる 場合もあった。Kの触媒活性についてはさらに検討が 必要である。

以上，触媒担持炭のプロファイルは，炭種によって も多少変化するが，全体的な傾向としては，ほとんど 触媒の種類とガス化剤によって決まることがわかっ た。

\section{3 触媒の活性序列}

すでに述べたように，反応のプロファイルが触媒に よって異なるので, 触媒間の比較をする場合, 初期の 速度だけではなく，その後の速度の変化も合わせて考 えなければならない。たとえば，新夕張炭の $\mathrm{Ni}$ 担持 炭と $\mathrm{Fe}$ 担持炭あるいは Grose Valley 炭のK担持炭 とBa 担持炭の $\mathrm{r}_{10}$ は，Table 3 に示すようにそれぞれ ほとんど同じであるが，プロファイルが異なるので総 合的には触媒効果に差がでてくる。そこで, 初期活性 とその後の速度の変化を反映した指標を種々検討した 結果, 反応時間60分に括ける転化率で，ある程度表現 できると考えられたので, 以下，その值を用いて触媒 活性の比較を行った。

各石炭の炭素含有量を横軸にとり, 各試料の60分の 転化率をプロットしたのがFig. 2〜4である。それぞ れ, $\mathrm{H}_{2} \mathrm{O}$ ガス化, $\mathrm{CO}_{2}$ ガス化, $\mathrm{H}_{2}$ ガス化に打ける結 果である。これらの図は, 本来, 線で結ぶべきすので はないが便宜上，触媒ごとに線で結んだ。すなわち， 線が交差しているところは序列が異なっていることを 示しまったく交差していなければ10炭種において序

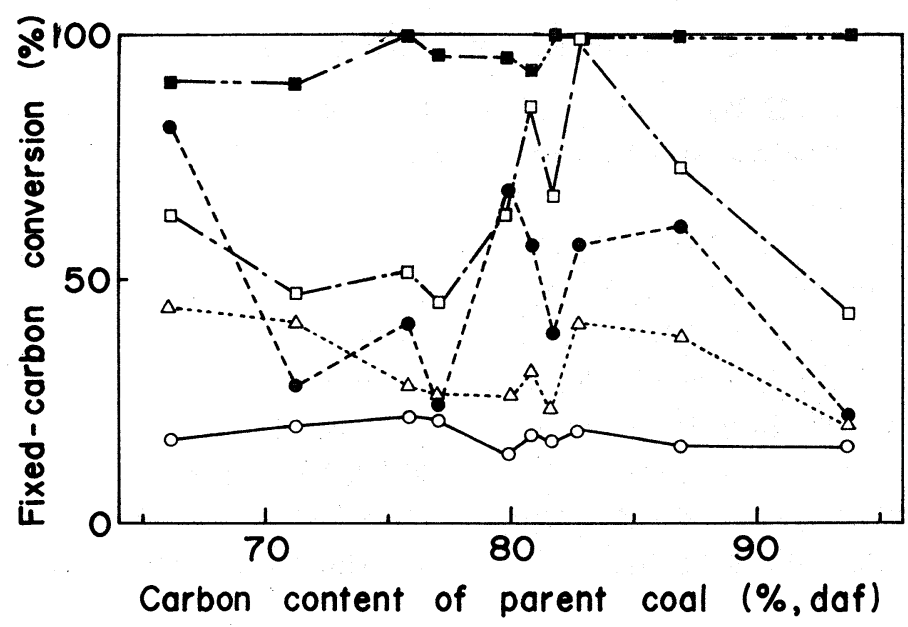

Catalyst : Potassium ; $\square$ Barium ; Nickel ; $\triangle$ Iron ; $\bigcirc$ None.

Fig. 2 Relative catalytic activity for the steam gasification of ten coals 


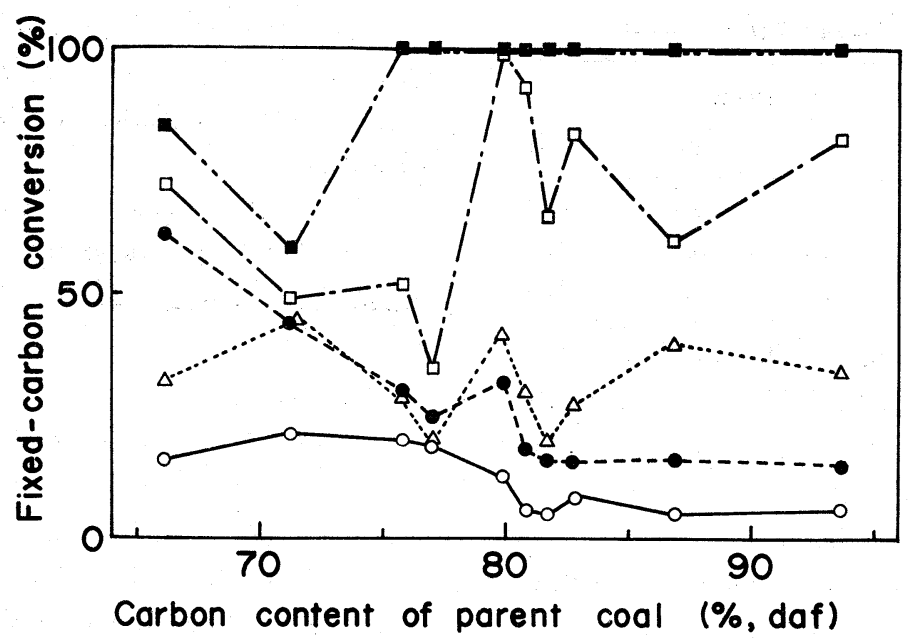

Catalyst: Potassium ; $\square$ Barium ; Nickel ; $\triangle$ Iron ; $\bigcirc$ None.

Fig. 3 Relative catalytic activity for the carbon dioxide gasification of ten coals

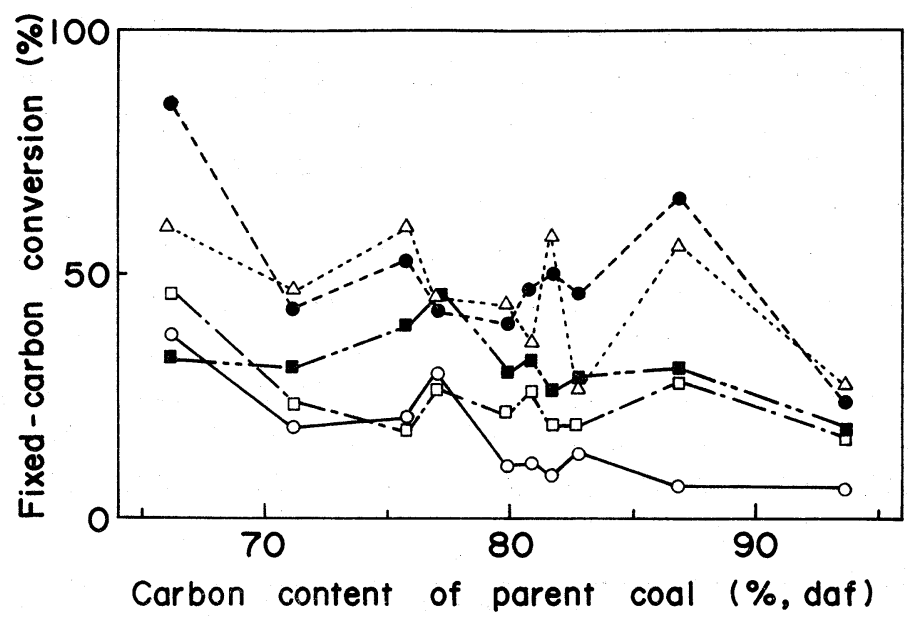

Catalyst: $\square$ Potassium ; $\square$ Barium ; Nickel ; $\triangle$ Iron ; $\bigcirc$ None.

Fig. 4 Relative catalytic activity for the hydrogasification of ten coals

列は変わらないことを示す。なお, $\mathrm{CO}_{2}$ ガス化におけ る反応温度は, South Beulah 炭は 923K, Yallourn 炭, Wandoan 炭, 太平洋炭は 973K, TatungYunkang 炭は 1023K, 新夕張炭, Grose Valley 炭, 赤平炭は1073K, Hongay炭, Leopold 炭は1123K で ある。

$\mathrm{H}_{2} \mathrm{O}$ ガス化 (Fig.2) に执いて, 多少の例外はある ものの触媒活性の序列は次のと和りである。

$$
\mathrm{K}>\mathrm{Ba}>\mathrm{Ni}>\mathrm{Fe}
$$

例外のなかで特筆されるものは，Yallourn 炭と Ni 触媒の組み合わせである。60分に拉ける転化率はFig.
2 に示すようにK担持炭に比べてやや低いが， $\mathrm{Ni}$ 担 持炭は特異な二段反応をしており，反応時間10分です でに65\%に達している。K担持炭の10分の転化率は45 \%である。このような特異な触媒効果は，より低温で

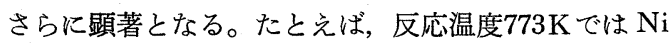
担持炭は 60 分で約 $80 \% 反$ 応するが，このような温度で は他の触媒は注とんど活性を示さずガス化は進行しな い。同様の現象が $\mathrm{CO}_{2}$ ガス化, $\mathrm{H}_{2}$ ガス化でも認めら れた。Yallourn 炭に打ける $\mathrm{Ni}$ 触媒の効果は, Ni の 高度な分散性 ${ }^{16) 17)}$ と関連があると考えられるが，この ことによって， Ni は潜在的には大きな活性をもって 
いるにもかかわらず，他の石炭では分散性の悪さから 十分にその能力を発揮できなかったものと思われる。 $\mathrm{CO}_{2}$ ガス化 (Fig.3) では， $\mathrm{H}_{2} \mathrm{O}$ ガス化同様 $\mathrm{K}$ の触 媒効果が最も大きく，次にBaの順であるが， Feと Ni の序列は逆転して次のようになった。

$\mathrm{K}>\mathrm{Ba}>\mathrm{Fe}>\mathrm{Ni}$

$\mathrm{Fe}>\mathrm{Ni}$ という序列は，とくに炭素含有量が $80 \%$ 以 上の石炭ではっきりしている。

$\mathrm{H}_{2}$ ガス化 (Fig.4) では, $\mathrm{H}_{2} \mathrm{O}$ ガス化, $\mathrm{CO}_{2}$ ガス 化に比べると， $\mathrm{K}, \mathrm{Ba}$ の効果が小さくなっており，ほ とんどの石炭で $\mathrm{Ni}, \mathrm{Fe}$ の遷移金属が上位にくる。ま た，線がかなり交差しており，触媒間の序列がはっき りしないところもあるが，全体的には次の序列が得ら れた。

\section{$\mathrm{Ni} \gtrsim \mathrm{Fe}>\mathrm{K}>\mathrm{Ba}$}

すでに述べたように， $\mathrm{H}_{2}$ ガス化では反応の 進行に 伴い, $\mathrm{Ni}$ 担持炭, $\mathrm{Fe}$ 担持炭の速度は一定あるいは増 加するが，K担持炭， $\mathrm{Ba}$ 担持炭の速度は減少する。 そのため，K, $\mathrm{Ba}$ の効果は小さくなっている。

\section{4. 結 論}

無煙炭から褐炭までの10種類の石炭を用い，4 種類 の触媒 $(\mathrm{K}, \mathrm{Ba}, \mathrm{Fe}, \mathrm{Ni})$ との組み合わせにより，触媒 活性序列および担持炭の反応のプロファイルを検討し た。さらに，それらに対するガス化剤の影響について 検討した結果, 次の結論を得た。

(1)触媒担持炭の反応のプロファイルは，炭種によっ てもある程度影響されるが， 汪とんど触媒の種類とガ ス化剂によって決まる。

(2)触媒間の活性序列は外少の例外はあるものの， ほ とんど炭種によらず，次のと拈りである。

$$
\begin{aligned}
& \mathrm{H}_{2} \mathrm{O} \text { ガス化; } \mathrm{K}>\mathrm{Ba}>\mathrm{Ni}>\mathrm{Fe} \\
& \mathrm{CO}_{2} \text { ガス化; } \mathrm{K}>\mathrm{Ba}>\mathrm{Fe}>\mathrm{Ni} \\
& \mathrm{H}_{2} \quad \text { ガス化 } ; \mathrm{Ni} \geq \mathrm{Fe}>\mathrm{K}>\mathrm{Ba}
\end{aligned}
$$

\section{[謝辞]}

本研究を行らにあたり，実験に協力していただいた 当研究所の庄司和江嬢, 高橋典子さんに感謝いたしま 于。

\section{文 献}

1) Haynes, W. P., Gasior, S. J. and Forney, A. J., in “Advances Chemistry Series”, Am. Chem. Soc., Washington, D.C. 131, 179 (1974)

2) Kayembe, N. and Pulsifer, A. H., Fuel, 55, 211 (1976)

3) Veraa, M. J. and Bell, A. T., Fuel, 57, 194 (1978)

4) McKee, D. W. and Chatterji, D., Fuel, 59, 308 (1980)

5) McKee, D. W., Carbon, 16, 53 (1978)

6) McKee, D. W., Carbon, 17, 419 (1979)

7) Otto, K., Bartosiewicz, L. and Shelef, M., Carbon, 17, 351 (1979)

8）笠岡成光，阪田裙作，柏野 茂，化学工学論文集, 8, 51 (1982)

9) Hippo, E. J., Jenkins, R. G. and Walker, P. L. Jr, Fuel, 58, 338 (1979)

10) Tomita, A., Takarada, T. and Tamai, Y., Fuel, 62, 62 (1983)

11) Solano, A.L., Mahajan, O.P. and Walker, P. L. Jr, Fuel, 58, 327 (1979)

12) Beesting, M., Hartwell, R. R. and Wilkinson, H.C., Fuel, 56, 319 (1977)

13) Tomita, A., Mahajan, O.P. and Walker, P. L. Jr, Fuel, 56, 137 (1977)

14) Otto, K., Bartosiewicz, L. and Shelef, M., Fuel, 58, 565 (1979)

15) Walker, P. L. Jr, Shelef, M. and Anderson, R. A., "Chemistry and Physics of Carbon", Dekker, New York, 4, 287 (1968)

16) Tomita, A., Ohtsuka, Y. and Tamai, Y., Fuel, 62, 150 (1983)

17）東山和寿, 富田 彰, 玉井康勝, 化学系学協会連 合東北地方大会予稿集，p.80（1981） 


\title{
Activity Sequence of Catalysts on Catalytic Coal Gasification
}

-Effect of Coal Type and Gasifying Agent-

\author{
Tákayuki TAKARADA, Yasuo OHTSUKA, Akira Tomita \\ and Yasukatsu TAMAI
}

(Chemical Research Institute of Non-Aqueous Solutions, Tohoku University)

SYNOPSIS :- Ten coals ranging from anthracite coal to brown coal were impregnated with four catalysts (K, Ba, Fe, Ni) during pulverization. Three different gases, that is, $\mathrm{H}_{2} \mathrm{O}, \mathrm{CO}_{2}$ and $\mathrm{H}_{2}$ were used to determine the effect of gasifying agent on the activity sequence of catalysts. The gasification was carried out in a thermobalance.

The reaction profile (the variation of specific rate with fixed-carbon conversion) strongly depended on catalyst type and reaction atmosphere, but was almost independent of coal type. The activity sequence of catalysts was also independent of coal type, and the sequences obtained were as follows;

$$
\begin{aligned}
& \mathrm{H}_{2} \mathrm{O} \text { gasification } \mathrm{K}>\mathrm{Ba}>\mathrm{Ni}>\mathrm{Fe} \\
& \mathrm{CO}_{2} \text { gasification } \mathrm{K}>\mathrm{Ba}>\mathrm{Fe}>\mathrm{Ni} \\
& \mathrm{H}_{2} \text { gasification }: \mathrm{Ni} \gtrsim \mathrm{Fe}>\mathrm{K}>\mathrm{Ba}
\end{aligned}
$$

\section{Key Words}

Coal gasification, Catalyst, Coal rank,

Gasifying agent 